\title{
İslam Medeniyet Mirasının Evrensel Sosyal Bilim Anlayışına Katkıları Üzerine Bir Değerlendirme
}

\author{
An Evaluation of the Contributions of Islamic Civilization to Universal \\ Understanding of the Social Science
}

\author{
Dr. Öğr. Üyesi Enver Sinan MALKOÇ iD) 1
}

\begin{abstract}
$\ddot{O} z$
İnsanoğlu, kendisinin de bir parçası olduğu kâinatı tüm yönleriyle tanıma ve anlama yönünde bitip tükenmek bilmeyen bir çaba içerisindedir. Bunun için başvurulan bilgi türleri evrensel olsa da bu bilgilerin yorumlanma ve değerlendirilme aşamasında farklı medeniyetlerin kendi özgün nitelikleri belirleyici hale gelmektedir. Bu bağlamda İslam medeniyetinin de bilgi-bilimsel bilgi-sosyal bilim anlamındaki evrensel birikimden öncelikle beslendiğini, sonra bu birikimi kendi özgün değerleriyle yoğurarak geliştirdiğini ve yine tüm insanlığın istifadesine sunduğunu söyleyebiliriz. İslam medeniyetinin bilimsel bilgi birikimine yaptığ katkının değeri malumdur. Ancak bilgiye getirdiği özgün yorumun ve onu işleyiş şeklinin belki de daha değerli olduğu savunulabilir. Nitekim İslam medeniyetinin ulaştığı bilimsel bilgi birikimi Batı medeniyeti elinde çoktan aşılmış, ancak bu bilgiyi yorumlayarak hayata taşımadaki yüksek değerlerine asla yaklaşılamamıştır. Dolayısıyla mevcut bilimsel bilgi birikiminin İslam medeniyet mirasının sunduğu değerlerle tekrar yorumlanması, insanlığa büyük kazanımlar sağlayabilecektir. Bunun sosyal bilimlerde yapılması ise toplum içi ve toplumlar arası düzen, adalet ve refahın sağlanmasına hizmet edecektir.
\end{abstract}

Anahtar Kelimeler: Sosyal bilimler, sosyoloji, toplum, medeniyet, tarih

Makale Türü: Derleme

\begin{abstract}
Mankind is in an endless effort to recognize and understand all aspects of the universe that he is a part of. Although the types of information applied are universal, the distinctive characteristics of different civilizations are decisive in the interpretation and evaluation of this information. In this context, it can be said that Islamic civilization is also nourished by the universal accumulation of "knowledge - scientific knowledge - social science" primarily. Later, Islamic civilization was integrated its own unique values into this knowledge during the development phase and presented it to the benefit of all humanity. The value of the contribution of Islamic civilization to the scientific knowledge is well known. However, it can be argued that the distinctive methodology and way of interpretation of the knowledge could be more valuable. As a matter of fact, the scientific knowledge accumulated by Islamic civilization has already been overtaken by Western civilization, but interpretation and bringing it to life with high values has been never achieved. Therefore, the reinterpretation of the rich scientific knowledge gained in today's world with the values presented by the heritage of Islamic civilization will provide great gains for humanity. Doing so in social sciences will serve to ensure inter-community and inter-communal order justice and prosperity.
\end{abstract}

Keywords: Social sciences, sociology, society, civilization, history

Paper Type: Review

\footnotetext{
${ }^{1}$ Sağlık Bilimleri Üniversitesi, Sağlık Bilimleri Fakültesi, sinan.malkoc@sbu.edu.tr.

Atıf için (to cite): Malkoç, E. S. (2019). İslam Medeniyet Mirasının Evrensel Sosyal Bilim Anlayışına Katkıları Üzerine Bir Değerlendirme. Afyon Kocatepe Üniversitesi Sosyal Bilimler Dergisi, 21(Prof. Dr. Fuat Sezgin Özel Say1s1), 1-15.
} 


\section{Giriş}

Bugün bilim dünyasının genel kabulüne göre bir bilginin bilimsel sayılabilmesi için objektif ve test edilebilir nitelikte olmas1 gerekmektedir. Yine ayn1 sebeplerin her zaman aynı sonuçları doğurması prensibi de bilimsel bilginin olmazsa olmazları arasında kabul edilir.

Bilimsel bilgiyi diğer bilgi türlerinden ayıran bu niteliklerin Sosyal Bilimler açısından ne derece geçerli olduğu ise tartışıla gelen bir problemdir. Aynı sebeplerin sosyal olaylarda her zaman aynı sonuçları doğurmayacağı iddiasından hareketle sosyal bilimlerin bilimsel nitelikleri sorgulanabilmektedir. Hâlbuki sosyal bilimciler olarak bizler, aynı sebeplerin toplumsal olaylarda da aynı etki potansiyeline sahip olduklarını savunuyor, ancak sosyal olayların çok sebepli ve çok sonuçlu olmaları sebebiyle bu alanda birbirinin tamamen aynısı denilebilecek iki olaya rastlamanın zorluğuna dikkat çekiyoruz. Sosyal olaylar için "iki kere iki dört eder" kesinliğinde bir önerme ileri sürülerek "şöyle bir sebep her olayda böyle bir sonuç doğurur" kesin yargısına varılabilmesi elbette ki mümkün değildir. Ancak bunun sebebi sosyal olgularda sebep sonuç ilişkilerinin saptanamazlığı değil, sosyal olayların arka planlarında her birisi farklı sebep sonuç iliş̧kileri taşıyan birçok farklı olgunun yer almasıdır. İşte bu noktada toplum biliminin işlevi bu sosyal olguların yapılarını, sebep sonuç bağlantılarını ve diğer olgularla ilişkilerini çözümlemeye çalışmaktır.

Sosyal olayların da böyle bilimsel bir sistematikle ele alınıp incelenebileceği gerçeği Batılı bilim adamları tarafından ancak 19. Yüzyıl başlarından itibaren dile getirilmeye başlanmıştır. Hâlbuki benzer bakış açısının İslam medeniyet havzasında çok daha önceden geliştirildiği bilinmektedir. Her şeyden önce İbn-i Haldun'un (1332-1406) çalışmalarının Tarih ve Sosyoloji bilimleri açısından bir milat durumunda olduğu inkâr edilemez bir gerçektir.

Bununla birlikte kendi medeniyet havzamızdaki zengin sosyal bilimler mirasının uzunca bir süredir atıl kalması ve bu alandaki çalışmalarımızın 19. yüzyıldan itibaren neredeyse tümüyle Batılıların genel kabulleri üzerinden yürütülmesi, toplumsal realitemizin bilimsel açıdan idrakinde bir takım yetersizliklere yol açmıştır. Nitekim Batı medeniyeti içinde yetişerek dünyaya bu pencereden bakan bilim adamlarının ne derece objektif ve evrensel açıklamalara ulaşabileceği, dolayısıyla da bu açıklamaların bizim sorularımıza ne derece cevap üretebileceği önemli bir sorunsal durumundadır. Zira bir toplumun kendisine ait yapısal ve işlevsel özellikleri onun içinde gerçekleşen toplumsal olayların sebep sonuç ilişkilerini de etkilemektedir. Bunun için belli bir toplumun tecrübelerinden hareket ederek evrensel sosyal bilim yasalarına ulaşma iddiaları gerçekçi olmamaktadır.

$\mathrm{Bu}$ durumda Batılı bilim adamlarının kendi tarihsel tecrübelerinden yola çıkarak yaptıkları toplumsal okumalar çoğu kez bize uymamaktadır. Zira Batı toplumları ile aramızdaki yapısal ve işlevsel farklılıklar, toplumsal olayların çok sebepli yapısını etkilemekte, bu da çok sonuçlu tablodaki farklılıkla kendisini göstermektedir. Dolayısıyla sosyal bilimler alanında daha isabetli sonuçlara varabilmemiz için kendi toplumsal gerçekliğimizden ve kendi toplumsal tarih okumalarımızdan yola çıkarak geliştireceğimiz sosyal bilim çalışmalarına ihtiyacımız vardır.

$\mathrm{Bu}$ noktada; bilgi, bilimsel bilgi ve sosyal bilimler kavramları ile bilimsel bilgide nesnellik tartışmaları üzerinde durmak, bu noktadan hareketle farklı medeniyetlerin kendi özgün dinamiklerinden yola çıkarak dünya bilim tarihine katkı sağlayabildiklerini vurgulamak, İslam medeniyet mirasının evrensel sosyal bilimlere ve sosyal bilim anlayışına katkılarını da bu bağlamda değerlendirmek durumundayız.

\section{Bilimsel Bilgi}

İnsan, hem akıl hem de nefis sahibi olması bakımından diğer canlı türlerinden ayrılan müstesna bir varlıktır. Akıl sahibi olması, insanı içinde bulunduğu âlemi anlama, yorumlama, onun üzerine fikir yürütme gibi düşünsel faaliyetlere sevk etmiştir. Bu noktada sadece varlığın kendisi değil, ona dair bilgi edinme şekli de düşünsel faaliyetlerin odağında yer almıştır. Böylece 
varlık felsefesi (ontoloji) ve bilgi felsefesi (epistemoloji) konuları, insanoğlunun düşünsel serüveni içerisinde en temel tartışma alanları haline gelmiştir.

Ancak varlık ve bilgiye dair bilgi edinme yolu felsefeyle sınırlı sayılamaz. Varlığa ve bilgiye dair malumat edinme çabası sürdürülürken çeşitli bilgi edinme yol ve yöntemleri takip edilmekte ve ulaşılan sonuçlar, elde edilen bilgiler diğer insanlarla paylaşılarak eğitim yoluyla gelecek nesillere aktarılmaktadır. Bu noktada başvurulan bilgi türlerini kabaca gündelik bilgi, teknik bilgi, sanat bilgisi, dini bilgi, felsefi bilgi ve bilimsel bilgi şeklinde kategorize edebilmemiz mümkündür. (http://www.felsefe.gen.tr/) Varlığa dair açıklamalar getiren bu bilgi türlerinden her birisinin kendisine özgü bir kaynağı ve o kaynağa ulaşma şekli vardır. Söz konusu bilgi türlerinden herhangi ikisinin prensipte çatışma halinde olduğunu söyleyebilmek mümkün değildir. Ancak spesifik bir konuda ters düşebilmeleri mümkün olabilir.

Bu noktada; nesnel, genel/ olgusal, kesin, öngörü sağlayan, tekrarlanabilir, evrensel/ insanlığa mâl olmuş ve birikimli olarak ilerleyen nitelikleri, (http://felsefe.konulari.org/) bilimsel bilgiyi diğer bilgi türlerinden ayırt edici nitelikler olarak öne çıkmaktadır. "Özellikle sonuçların test edilebilmesi için sistemli olarak belli bir yöntem veya yöntemlerin kullanılması, bilimsel bilginin ayırt edici yönüdür.” (Ural, 1998: 14)

Burada, aynı sebeplerin her zaman aynı sonuçları doğurması (determinizm) ilkesine özellikle dikkat çekmek gerekiyor. Nitekim bilimsel bilginin yukarıda saydığımız ayırt edici niteliklerinden birçoğunun gelip bağlandığg, ifadesini bulduğu yer, determinizm ilkesi olmaktadır. Herhangi bir alana dair ulaşılan nesnel, olgusal, kesin ve tekrarlanabilir bilgi; bünyesinde doğal olarak determinizm ilkesini de barındıracaktır.

Bilimsel bilginin niteliklerini; matematik, istatistik gibi formel bilimlerde ve fizik, kimya, astronomi, jeoloji gibi doğa bilimlerinde nispeten daha açık ve net olarak görebiliriz. Örneğin matematikte; $2+2=4$ 'tür ve bu her zaman böyledir. Suyun deniz seviyesinde 0 derecede donup 100 derecede kaynaması da değişmez bir fizik kuralı durumundadır.

İnsanoğlu kâinatın fiziksel yapısına dair değişmez yasaların olduğunun bilincine vardıktan sonra bunları tespit edip öğrenme gayretine yönelmiştir. Bilimsel bilgi, insanoğlu açısından hem içinde var olduğu evrenin gerçeklerine dair merakını gidermesi hem de bu gerçekler üzerinden geliştireceği tekniklerle yaşamını kolaylaştırması bakımından vazgeçilmez bir uğraş halini almıştır.

İnsanoğlunun doğa bilimleri ve formel bilimlerle olan ilişkisini kısaca böyle izah edebiliyoruz. Pekiyi toplum bilimlerinin niteliği ve insanoğlunun onlarla olan ilişkisinin mahiyeti nedir? Bununla ilgili olarak neler söylenebilir?

\section{Sosyal Bilimlerin Bilimselliği}

Sosyal bilimler dergisi olması nedeni ile farklı alanlarda yayın yapıyor olsa da bu tüm yayınların bilimsel bir özellik taşıması gerektiği gerçeğini değiştirmez. Hangi alan ya da hangi makale türü olursa olsun mutlaka bilimsel bir yöntemin takip ediliyor olması gereklidir. Yapılan çalışmanın alanının ve türünün gerekliliklerine göre izlenen bilimsel yol yöntem ve teknikler bu başlık altında mutlaka verilmelidir. Bir arşiv araştırması ya da doküman analizi, bir durum çalışması ya da nicel verilerin toplandığı bir araştırma veyahut da bir literatür taraması, kısaca ne tür bir çalışma yapılmış olursa olsun çalışmanın bilimsel özelliklerinden bu başlık altında bahsedilmesi gereklidir. Gerektiğinde evren ve örneklem, katılımcılar, veri toplama araçları, verilerin toplanması ve analizi vb gibi alt başlıklarla bu bölüm ayrıntılandırılabilir.

Bilimsel bilgiyi diğer bilgi türlerinden ayıran niteliklerin Sosyal Bilimler açısından ne derece geçerli olduğu tartışıla gelen bir problemdir. Aynı sebeplerin sosyal olaylarda her zaman aynı sonuçları doğurmayacağı iddiasından hareketle sosyal bilimlerin bilimsel nitelikleri sorgulanabilmektedir. 
Hâlbuki sosyal bilimciler olarak bizler, aynı sebeplerin toplumsal olaylarda da aynı sonuçları doğuracağını savunuyor, ancak sosyal olayların çok sebepli ve çok sonuçlu olmaları sebebiyle bu alanda birbirinin tamamen aynısı denilebilecek iki olaya rastlamanın zorluğuna dikkat çekiyoruz.

İnsan, -yukarıda da değindiğimiz gibi- nasıl ki fizik evreni ve doğayı tanıma ihtiyacı duymuş ve onda değişmez yasalar olduğunu anladıktan sonra bunları tespit etme arayışına girmişse, tarihin her döneminde toplumsal yaşama dair konulara da ilgi göstermiş, bu konularda da fikir yürütmüştür. Ancak topluma yönelik bu uğraşlar, genellikle felsefi bakış açısının ötesine geçmemiştir. Toplumsal işleyişin doğasında da değişmez yasaların olabileceği ve bunların da bir bilim disiplini içerisinde tespit edilip ele alınabileceği düşüncesi, doğa bilimlerine kıyasla daha geç ortaya çıkmıştır.

Bu konuda kayda değer ilk adımların İbn-i Haldun (1332-1406) tarafından atıldığını, sonrasında bu tür çalışmaların uzunca bir süre yine İslam dünyasında devam ettirildiğini belirtmek gerekiyor.

İbn-i Haldun'un toplumun doğasını bilimsel manada anlama çabasına Kur'an'1 Kerim'deki bir takım bilgilerden ilham alarak girişmiş olduğu düşünülebilir. Bu konuda Kur'an'1 Kerim kaynaklı sünnetullah terimi özel bir yere ve öneme sahiptir. Sünnetullah; Kur'an'1 Kerim'de "sürekli, düzenli ve özgün uygulama" anlamında kullanılan sünnet kelimesinin Allah'a nisbet edilmesiyle geliştirilen bir terimdir ve "Allah'ın tabiatı yaratıp devam ettirmek ve toplum hayatını düzenlemek üzere koyduğu kanunlar" (Çelebi, 2010: 159) anlamına gelmektedir. Bu noktada terimin sadece tabiatla değil aynı zamanda ve belki de daha ağırlıklı olarak toplumun doğasıyla alakalı olduğunu söyleyebiliriz. Zira konuyla ilgili bazı ayetlerde bireysel ve toplumsal davranışların, tepkilerin ve Allah'ın buna vereceği karşıllğın örüntüleşmiş sürekliliği konu edilmektedir. Konuyla ilgili şu ayeti kerimeleri örnek olarak alabiliriz:

"Elçileri onlara açık belgelerle gelince, kendilerinde olan bilgiyle sevinip şımardılar da, alaya aldıkları şey onları sarıverdi. Baskınımızı gördüklerinde: 'Yalnız Allah'a inandık; O'na koştuğumuz eşleri inkâr ettik' dediler. Ancak, Bizim baskınımızı gördüklerinde inanmaları kendilerine yarar sağlamadı. Bu, Allah'ın kulları hakkında (öteden beri) süregelen uygulamasıdır. İște inkârcılar o zaman kayba uğradılar.” (Mü’min 40/83-85)

"Bu (Firavun ve kavminin cezalandırılmaları), bir toplum kendi içindekini değiştirmedikçe, Allah'ın da o topluma verdiği nimeti değiştirmeyeceğindendir. Allah işitendir, bilendir." (Enfal 8/53)

"İnsanlara doğruluk rehberi gelmişken, onları inanmaktan ve Rablerinden bağışlanma dilemekten alıkoyan, öncekilere uygulananın kendilerine de gelmesini veya azabın karşılarına gelmesini beklemelerinden başka bir şey değildir." (Kehf 18/55)

İslam dünyasındaki düşünürler toplumsal olgular arasında nedensellik bağları kurulabileceğine dair fikirlerle 14. Yüzyıldan itibaren yüzleşmişlerken Batı'da toplumsal olguların sebep sonuç ilişkilerinin çözümlenebileceğine dair bir bakış açısının gelişmeye başlaması ancak İbn-i Haldun'un çalışmalarının 19. yüzyıl başlarında Batı dillerine çevrilmesinden (Bayrakdar, 2012: 103) sonra gerçekleşmiştir. Comte'a göre "toplumun yeni bilimi, metafizik kalıntılardan kurtularak diğer bilimlerle aynı kapsayıcı mantıksal biçimi paylaşmak durumundadır." (Giddens, 1997: 247) (Burada metafizik ifadesiyle, salt akıl yürütme yoluyla ulaşılan felsefi bilgilere işaret edilmektedir).

Aynı zamanda modern bir bilim anlamında sosyolojinin isim babası da olan Auguste Comte, bilimlerin ihtiyaçlar sonucu ortaya çıktığına vurgu yapar. Ona göre sosyoloji; matematik, astronomi, fizik, kimya, biyoloji gibi bilimlerden sonra; teolojik, metafizik, pozitif şeklinde sıraladığı evrimsel aşamaların sonucunda ve bilimler hiyerarşisinin hem analitik hem de tarihsel anlamda tepesinde ortaya çıkmıştır. (Giddens, 1997: 246-247) 
19. yüzyıl, aynı zamanda Batı'da toplumsal dönüşüm ve çalkantıların ileri boyutlarda yaşandığı bir dönemdir. Ekonomi ile psikoloji bilimlerinin ardından (ve onların yetersiz kalmaları üzerine) sosyoloji ile antropoloji bilimleri de bu çalkantıların çözümü, toplumsal düzen ve istikrarın tesisine katkı sağlamaları umuduyla geliştirilmiştir. (Sezer, 1985: 71)

Böylece sosyal bilimlerden önemli ölçüde yararlanılmıştır ve sürüp giden çeşitli problemlerin çözümü için halen yararlanılmaktadır. Ancak zaman, sosyal bilimlerde değişmez yasalara ulaşmanın, toplumsal olguları kesin ve net çizgilerle ifade etmenin, doğa bilimlerindeki kadar kolay olmadığını göstermiştir.

Toplumsal olayların çok sebepli-çok sonuçlu olmaları ve toplumsal olguların diğer toplumsal olgularla girift bir ilişki içinde bulunmaları, sosyoloji alanında keskin yargılara varmayı zorlaştırmaktadır.

Hâlbuki Batıda Auguste Comte öncülüğünde geliştirilen "pozitivist yaklaşımı benimseyenler, pozitif bilim yöntemleriyle toplumun yasalarının keşfedileceği, toplumun daha iyi bir gelecek için yönlendirilebileceği ve daha iyi bir toplumsal yapının inşa edileceği düşüncesine sahiptirler". (Zencirkıran, 2015: 30) Comte'a göre sosyoloji, "insan davranışını anlamak, dolayısıyla da öngörmek ve denetlemek için bilimi kullanarak insanlığın refahına katk1da bulunmalıydı." (Giddens, 2000: 8)

$\mathrm{Bu}$ açıdan Batıda 19. yüzyılda pozitivizm akımıyla başlayarak peş peşe ortaya atılan Sosyoloji kuramlarının evrensel sosyal yasalara ulaşma, toplumsal tarihi okuma ve ileriye yönelik öngörülerde bulunma çabası gösterirlerken fazla iddialı olduklarını söyleyebiliriz. Auguste Comte'un üç hal yasası ve Karl Marx-Friedrich Engels ikilisinin tarihsel materyalizmi buna örnektir. Comte'un insan toplumlarının düşünsel gelişimini teolojik, metafizik ve pozitif dönemlere ayırırken, kendi içerisinde yaşadığı Batı toplumlarının tarihsel tecrübelerini baz aldığ anlaşılmaktadır. Aynı şekilde Marx'ın da içinde bulunduğu Batı sanayi toplumunun etkisi altında kalarak tarih okuması yaptığı ve ileriye yönelik öngörülerini yine aynı etki altında geliştirdiği görülmektedir. Sonuçta bu yorumlamalar, evrensel gerçekliği yakalamak şöyle dursun, sadece kendi toplumlarının gerçekliğini yakalamak ve tarihsel geleceğini öngörmekten dahi uzak kalmıştır. Comte'un öngördüğü şekilde din ve metafiziğin rafa kaldırıldığı üçüncü bir döneme girilemediği gibi Marx'ın öngördüğü şekilde sanayi toplumu da bir proletarya devrimi doğuramamış, aksine o günkü sanayi toplumu, bugün sanayi sonrası toplum denilen yeni bir toplum biçimine evrilerek bahsedilen türden bir devrimin varsayılan alt yapısını da ortadan kaldırmıştır.

Batıda on dokuzuncu yüzyıl, öznel şartların etkisinde kalınarak geliştirilen ama nesnel olma iddiasında bulunan, evrensel sosyal yasalara ulaşma ve toplumsal tarihi bütünüyle çözümleme iddiasındaki büyük anlatıların yüzyılıydı. Bunların yanılgıları fark edildikçe yirminci yüzyıl sosyal bilimlerde daha lokal, spesifik araştırmalara ve çözümleme çabalarına sahne olmuştur.

\section{Nesnel Bilimsel Bilginin Öznel Yorumlanışı}

Ünlü bilim tarihçisi Prof. Dr. Fuat Sezgin'in 1srarla vurguladığı gibi bilim evrenseldir ve insanlığın ortak mirasıdır. (Sezgin, 2011: 23) Yine bilim tarihçisi Ord. Prof. Dr. Aydın Sayılı'nın vurguladığı gibi ilmin özelliklerinden birisi yığılarak büyüyüp gelişmesidir ve bu yığılma evrenseldir. (Say1l1, 1963: 5) "İlim, tarih boyunca, Misır ve Mezopotamya'dan Yunanlilara, Yunanlılardan İslam Dünyasına, İslam Dünyasından da Avrupa'ya geçmiştir”. (Sayıl1, 1963: 6) İlmi gerileme denildiğinde genel olarak ilmi bilginin azalması değil, ilmi çalışma ve araştırmanın azalması, duraklaması anlaşılır. İlmi bilginin azalması, istisnai olarak Orta çağ Avrupa'sında görülmüştür. (Say1lı, 1963: 6)

Bilimsel bilginin bu evrensel niteliğine karşın farklı medeniyetlerin varlık ve bilgi gibi konuları incelerken, algılarken, yorumlarken ve hayata uyarlarken özgün bakış açıları 
sergiledikleri de inkâr edilemez bir gerçektir. Kısacası, bilimsel bilgi nesnel ve evrensel iken, onun farkı medeniyetler bünyesinde yorumlanışı öznel olmaktadır.

Gözlem, deney, anket, mülakat gibi yöntemlerle ulaşılan veriler bizim için toplumun fotoğrafını çekebilir, nesnel veriler sağlayabilirler. Ancak sıra bu bilgilerin yorumlanmasına geldiğinde tarihi, coğrafi, kültürel vb. etkiler altındaki bireye ait psikolojik vb. bireysel faktörler kaçınılmaz olarak devreye girerek olaya öznel nitelik kazandıracaktır.

Her türden bilgide olduğu gibi bilimsel bilginin yorumlanması sırasında da toplumsal ve bireysel faktörler devreye girmektedir. Yorumlamayı yapan bilim adamları zaten içinde yaşadıkları toplumca paylaşılan inanç sisteminin, coğrafi çevrenin, tarihi, kültürel vb. özelliklerin bir şekilde etkisi altındadırlar. $\mathrm{Bu}$ etkiler toplamı, bilginin toplumdan topluma farklı yorumlanmasını beraberinde getirmektedir. Hatta yorumlardaki farklılık toplumlararası boyutta kalmamakta, bireysel boyuta kadar inmektedir. Zira aynı toplum içinde yaşayıp benzer toplumsal etki altında bulunan bireyler arasındaki psikolojik vb. farklılıklar, yorumların bireyden bireye de değişkenlik gösterebilmesine yol açmaktadır.

Özetle ifade edecek olursak; bilimsel bilginin nesnelliği ve evrenselliği nasıl bir gerçeklik ise; bu bilginin yorumlanış ve hayata geçirilişinde rol oynayan medeniyetler, bireyler ve toplumlar arası farklılıkların da başka bir gerçeklik olduğunu söyleyebiliriz.

Dolayısıyla antik Yunan döneminde belli bir noktaya getirilen bir bilginin İslam medeniyeti içerisinde ele alınarak onun kendi bakış açısıyla yoğrulup geliştirilmesi ve buradan modern Batı medeniyetine aktarılarak bir kez de onların elinde yoğrulması gerçeğinin sayısız örneğine rastlanabilmektedir. Bu, sosyal bilimler için olduğu kadar doğa bilimleri için de geçerli olan bir durumdur.

Saptamamızı bir misalle somutlaştırmak gerekirse; el-Cahız, İbn Miskeveyh gibi birçok Müslüman bilim adamı evrim teorisini Darwin'den yaklaşık bin yıl önce ortaya atmış, sonrasında sürdürmüş, ancak bunu İslam inanç sistemi dışında yorumlamamışlardır. Onlara göre biyolojik evrim, tabiatın işleyişi içerisinde gerçekleşen bir olaydı ve bu işleyişi düzenleyen, tabiat kanunlarını yaratan, neticede yine Allah'tı. (Yakıt, 1984: 101-102) Zaten Müslüman bilim adamları bilime her zaman; yaratıcının yaratılmışlar âlemine koyduğu işleyiş kurallarının (sünnetullahın) anlaşılıp öğrenilmesi olarak bakmışlardır. Buna karşılık Batı'da aydınlanma çağı sonrası belli bir trend yakalayan seküler bilim anlayışının genelde bilimi, özelde ise evrim teorisini ele alış biçimi farklı olmuştur. Darwin ve ardılları tarafindan evrim; canlı nesillerinde gerçekleştiği varsayılan tekâmül sürecinde yaratıcı faktörünü devre dışı bırakan ve bu süreci muhtelif şartların tesadüfi buluşmalarıyla açıklayan bir anlayışla ele alınıyordu.

$\mathrm{Bu}$ misal için açtığımız parantezi kapatarak tekrar konumuzun akışına dönecek olursak; on dokuzuncu yüzyıl Batılı bilim anlayışındaki yanılgı kaynağının belki de bir yönüyle; bilimsel bilginin kendisini ve bilimsel bilginin yorumlanışını aynı konumda görüp bunları birbirlerinden ayırt etmeyen anlayış olduğunu söyleyebiliriz. O günün bilim adamları ulaştıkları nesnel verileri kendilerince yorumluyor ve vardıkları açıklamaları da bilimsel bir bilgi zannediyorlardı.

Hâlbuki Batılı bilim adamlarının kendi tarihsel tecrübelerinden yola çıkarak yaptıkları toplumsal okumalar çoğu kez bize uymamaktadır. Zira Batı toplumları ile aramızdaki yapısal ve işlevsel farklılıklar toplumsal olayların çok sebepli yapısını etkilemekte, bu da çok sonuçlu tablodaki farkl11ıkla kendisini göstermektedir.

Dolayısıyla her ne kadar bugün Batı medeniyetinin etkisi altında kısmen dejenerasyona uğramış da olsa bizler esasta ondan farklı ve özgün yapıya sahip bir medeniyetin çocuklarıyız. İște burada, mensubu bulunduğumuz medeniyetin sosyal bilimlere bakışındaki orijinalliği, özgünlüğü yakalamaya, anlamaya çalışmak durumundayız. Bu noktada önce; medeniyetimizin yetiştirdiği bilim insanlarının dünyanın ortak sosyal bilimler birikimine, mirasına katkılarını bazı örneklerle yetinerek de olsa hatırlamak isabetli olacaktır. 


\section{4. İslam Medeniyetinin Sosyal Bilimlere Katkıları}

Dünya genelinde doğa bilimleri alanında El Biruni, Cabir bin Hayyan, Battani, İbn-i Sînâ, Harezmi, İbn-i Heysem, Giyaseddin Cemşid ne anlam ifade ediyorsa; Felsefede Farabi, -yineİbn-i Sina, İbn-i Rüşd ne değer taşıyorsa; Sosyal bilimlerde İbn-i Haldun'un, Kindî’nin, Câhız’ın, Mes'ûdî'nin de böyle bir anlamı, böyle bir değeri vardır.

İslam dünyasının ilk filozofu olarak kabul edilen Kindî (796-868), aynı zamanda psikoloji alanında da önemli çalışmalara imza atmıştır. "İslâm felsefe tarihinde aklın içeriği ve fonksiyonu üzerine eser yazan ilk filozof Kindî’ dir. Bu bağlamda Kindî‘eye, psikofizyoloji dalının İslâm felsefesindeki ilk temsilcisi denilebilir." (Korkman, 2017: 15) Kindi, metafiziği geometri ve fizik üzerinde temellendirmeye yönelik orijinal çalışmalar yapmıştır. Sara ve sinir hastalıklarının tedavisi için musiki ile tedaviyi ilk uygulayan kişi olarak bilinmektedir. Akıl ve nefis üzerine eserler vermesinin yanı sıra, uyku ve rüya olaylarını bilimsel olarak açıklayan ilk eserin yazarı da kendisidir. (Bayrakdar, 2012: 164-166)

Câhız (772-869); ilahiyat ve zoolojinin yanı sıra tarih, psikoloji ve sosyal psikoloji alanlarında bilimsel faaliyet göstermiştir. Cimrilik, kibir, kıskançlık, cinsiyet gibi konularda müstakil eserler yazarak bu konulara psikolojik bir yaklaşımla 1şık tutmuştur. Tabii çevrenin insan ve hayvanlara etkisi üzerinde durmuş, sosyal çevrenin birey üzerindeki etkisini önemle vurgulamıştır. (Bayrakdar, 2012: 45-47) Ayrıca "hayvanların insanlar gibi sosyal ve psikolojik hayatları olduğunu söyleyerek, günümüzdeki hayvan sosyolojisi çalışmalarına da öncülük etmiştir." (Bayrakdar, 2012: 47) Câhız'ın, özellikle sosyal çevrenin bireye etkisiyle ilgili görüşlerinin, ünlü Batılı sosyolog Emile Durkheim'a 1100 yıl farkla öncülük ettiğini söyleyebiliriz.

Botanik alanındaki çalışmalarıyla eski Yunanları aşmış olan (Sezgin, 2008, 19) Dineverî (828-895); ilk insandan kendi yaşadığı döneme kadar tüm insanlığın tarihini yazmış, ayrıca Türklerin ve Kürtlerin soy kütüklerini araştıran müstakil bir eser kaleme almıştır. (Bayrakdar, 2012: 59) Dineverî’nin, yaptığı çalışmalarla etnografya bilimine öncülük ettiği görülmektedir.

Kimya ve tıp alanındaki çalışmalarıyla öne çıkan Ebû Bekir Râzî (864-930), ayrıca beden ve ruh sağlığının birbirleri üzerindeki etkisi üzerinde durmuş, böylece İslam felsefesinde ilk psikosomatik yaklaşımı oluşturmuştur. Ruhsal hastalıkların tedavisinde telkinin önemine vurgu yapan Râzî, "Kitab"ul-Havi isimli eserinde, melankolinin farklı tiplerine, hipokondriye, mizacın kişilik üzerindeki etkilerine, uyuşukluk, zihin tembelliği, zihni karmaşa, akıl, uykusuzluk hastalıklarına ve tedavilerine de değinmiştir." (Korkman, 2017: 16)

Daha çok felsefi yönüyle tanınan Farabi (870-950) siyaset, psikoloji, ahlak gibi konularla da ilgilenmiştir. Kendisi, İslam dünyasında siyaset felsefesinden ilk bahseden filozoftur. Kavramları analitik ve sentetik olarak ikiye ayırarak Batı'daki Leibniz ve Kant'a öncülük etmiştir. (Bayrakdar, 2012: 71) Farabi ayrıca bilgi problemi üzerinde durmuş ve bu kavramı akıl ve nefs kavramları doğrultusunda incelemiştir. (Korkman, 2017: 17)

İbn-i Haldun tarafından tarihçilerin pîri olarak tanımlanan Mes'ûdî (893-956), başlangıçtan kendi yaşadığ döneme kadar araştırıp yazdığ 1 tarihsel bilgileri coğrafyayla birlikte ele alır. "Coğrafya açısından en önemli sayılabilecek görüşü belirli bir bölgenin coğrafyasının o bölgedeki insan, hayvan ve bitki örtüsünü doğrudan etkilediğine dair kanaatidir". (Avc1, 2004:353) Ayrıca gökbilim, meteoroloji ve önemli milletlerin tarihini birlikte ele aldığı başka bir eseri daha vardır. (Bayrakdar, 2012: 177-178) Kendisi, "geçmişte ve onun bulunduğu dönemde bilinen bütün kültürleri ve medeniyetleri tanıtma girişimi” göstermiştir. (Sezgin, 2008: 23) Dolayısıyla Mes'ûdî’nin sosyal antropoloji açısından öncü ve disiplinler arası çalışma konusunda önemli bir isim olduğunda şüphe yoktur.

Aslında doğa bilimleri alanında büyük bir isim olan El Biruni (973-1050), Hindistan'a dair yazdığı eserde Hint kültürünü ve dinlerini açık bir nesnellikle ve Yunan kültür ve diniyle karşılaş̧tırmalı olarak ele almıştır. Kendisi bu eseri, bizzat Hindistan' da yaşadığı dönemde yaptığı 
araştırmalar doğrultusunda ortaya koymuştur. "El Biruni’nin Hindistan kitabı yabancı uygarlıkların tanıtılmasında aşılamamış bir zirvedir, hatta sadece Arap- İslam kültüründe değil.” (Sezgin, 2008: 33) Bu durum, El Biruni’yi de sosyal antropolojinin öncü ve büyük isimlerinden birisi haline getirmektedir. Ayrıca yabancı kültürlere karşı Batı geleneğinde var olan küçümseyici, dışlayıcı ve imha edici gelenek yerine araştırmaya, öğrenmeye ve anlamaya dönük yaklaşım için de çok değerli ve 1şık tutucu bir örnektir.

İbn-i Sîna (980-1037) asıl uzmanlık alanı olan tıp ve felsefenin yanı sıra, psikoloji ve psikiyatri alanında da önemli çalışmalara imza atmıştır. "Ruh ve sinir hastalıklarının tedavisinde ilk defa psikanaliz ve psikiyatri yöntemlerine başvurmuştur." (Bayrakdar, 2012: 110) Böylece onun da Sigmund Freud'dan yaklaşık 800 sene önce bu yöntemleri kullanarak bir ilke imza attığı görülmektedir.

Yusuf Has Hacib (1017-1077); siyaset, ahlak, adalet ve edebiyat alanlarında önemli bir yere sahip olan Kutadgu Bilig isimli eserin yazarıdır. (Bayrakdar, 2012: 235) "Yusuf Has Hacib, birbirine çok sıkı bağlarla bağlı bulunan fert, cemiyet ve devlet hayatının ideal bir biçimde düzenlenmesinde zaruri olan zihniyet, bilgi ve faziletlerin nelerden ibaret olduğu, bunların nasıl elde edileceği ve nasıl kullanılacağı üzerinde sanatkârane bir şekilde durmuştur.” (Kaçalin, 2002: 478)

Abdülkahir bin Abdurrahman el Curcani (ö. 1078) dil alanında kullanılan ifadeleri sebep, amaç ve tesir esaslarına göre psikolojik açıdan kavramaya çalışmış ve stilistik gramerin temellerini atmıştır. (Sezgin, 2008: 33)

Kaşgarlı Mahmud (1008-1105), "modern anlamda bir dilbilimcidir". (Bayrakdar, 2012: 148) $\mathrm{Bu}$ durum; modern dilbilimcilerin kullandıkları metodolojiyi 7-8 asır önce keşfedip kullanarak onlara öncülük etmesi anlamına gelmektedir. Ayrıca meşhur eseri Divanü lugati’t Türk'ün herhangi bir sözlük ve gramer kitabı sayılamayacağını özellikle belirtmek gerekmektedir. Kaşgarlı Mahmud; Türk kültürü, etnolojisi, etnografyası, folkloru, mitolojisi, Türk ili coğrafyası, töre ve gelenekleri, şiiri, atasözlerindeki Türk felsefesi ve dünya görüşü, tıbbi usullerden farmakolojiye, spordan yemek adlarına kadar "günlük hayatın akla gelebilecek nesi varsa münasebet düşürerek muhatabını bilgilendirmeyi gaye edinmek suretiyle eserine bir nevi 'Türkiyyat' ansiklopedisi olma hüviyet ve değerini de kazandırmıştır'. (Akün, 2002: 13) Bu durum onu da sosyal antropolojinin öncü isimlerinden birisi haline getirmektedir.

İbn Rüşd (1126-1198), tıp, optik, felsefe ve astronominin yanı sıra İslam hukuku alanında da önemli çalışmalar yapmış olan çok yönlü bir bilim adamıdır. (Bayrakdar, 2012: 106-107)

Yusuf bin Ebu Bekr es-Sekkâkî (1160-1229); dil biliminin "stil grameri" ve "resimsel dil" olarak adlandırılabilen disiplinler arası iki önemli alanında çok önemli prensipler ortaya koymuş ve büyük başarılar elde etmiş̧ir. (Sezgin, 2008: 52) Bu çalışmalar, lisanın psikolojik süreçlerle ilişkisini ortaya koyma yolunda çok önemli bir yere sahiptir. Hatta gerek Curcani'nin, gerekse Sekkaki'nin dil ve algı arasındaki ilişkiye getirdikleri açıklamaların, çok çok önden giderek Wittgenstein, Husserl, Carnap, Russel, Reichenbach gibi 20. Yüzyıl filozoflarına alan açtı̆̆ını söyleyebiliriz.

İbn Haldun (1332-1406); "umran ilmi adı altında tarih felsefesi, sosyoloji ve ekonomi gibi insan ilimlerinin kurucusu sayılır". Ona göre "Tarih, salt olaylar zincirini anlamak değildir". "Tarihin de tabiat ilimleri gibi ilke ve yöntemleri olduğunu" ilk kez o ortaya koymuş, tarihte; "metafizikte ve fizikte olduğu gibi bir sebeplilik ilkesi olduğunu, değişken şeyler olduğu gibi, değişmeyen ilkeler ve kanunlar da" olduğunu göstermiş̧tir. Kendisi "devleti, kurumları ve sosyal olayları, biyolojik veya uzviyetçi bir teoriyle açıklar". Machiavelli, Vico, gibi Batılı düşünürler üzerinde etkisi olmuş; Montesquieu, Toynbee gibi Batılı düşünürler de ona benzetilmiştir. İbn Haldun'un Mukaddime isimli eseri 19. yüzyılın başında birçok Batı diline tercüme edilmiştir. (Bayrakdar, 2012: 103-104) Daha önce de vurguladığımız gibi, Batıda sosyal bilimlerin 19. yüzyıldan itibaren inkişaf etmesinde bu tercümelerin önemi inkâr edilemez durumdadır. Örneğin; 
İbn-i Haldun'un 19 ve 20. yüzyıl sosyologlarının organik teorilerine ve yapısalcı akımlarına 600 yıl önceden 1şık tutmuş olması açık bir gerçektir.

Ali Kuşçu (ö. 1474); bir bilgin olarak matematik ve astronominin yanında kelam ve Arapça dilbilim konularında da önemli hizmetler vermiştir. (Bayrakdar, 2012: 31)

Kâtip Çelebi (1609-1657); tarih, coğrafya, siyaset ve din konularında çalışmalar yapmıştır. O da Hazreti Âdem'den kendi yaşadığı döneme kadar geçen tüm tarihi yazmıştır. Bilim tarihi üzerine de önemli çalışmaları vardır. Keşfu'z zunûn isimli eserinde 10.000 yazar ve 14.500 kitabın tanıtımını yapmıştır. "Tarihle ilgili en önemli görüşü, tarihin geçmişin bir ilmi değil, esasen geleceğin bir ilmi olarak görülmesi anlayışıdır”. Ayrıca İbn-i Haldun gibi o da tarihi olayların nedensellik ilkesiyle anlaşılması gerektiğini vurgulamıştır. (Bayrakdar, 2012: 150-151)

Evliya Çelebi’nin (1611-1684) "Seyahatname" isimli eseri; tarih, coğrafya, etnoloji, kısaca kültür tarihi açısından çok kıymetli bir kaynaktır. Evliya Çelebi, gezdiği yüzlerce şehir ve binlerce köy hakkındaki bilgileri, evsaf adı altında sistematik bir şema içerisinde aktarmaktadır. Bu bilgiler; gezilen yerlerdeki idari durum, tarihçe, konum ve genel görünüm, mahalleler, adının kaynağı, her çeşit mimari eser, eğitim kurumları, halkın eğitim düzeyi, hanlar, tekkeler, mesire yerleri, hamamlar, çarşı-pazarlar, kahvehaneler ve sosyal yaşam, kadın ve erkek adları, giyim tarzları, yiyecek ve içecekler, geçim kaynakları, üretim malları, iklimi ve türbeleri şeklinde bir sıralamayla aktarılmaktadır. (Tezcan, 2009: 16) Söz konusu çalışmanın sosyolojik ve antropolojik açıdan çok değerli ve çok yönlü bir hazine durumundadır.

Ahmed Cevdet Paşa (1823-1895); özellikle tarih ve İslam hukuku alanlarındaki çalışmalarıyla öne çıkan hem bir bilim adamı hem de bir devlet adamıdır. Devrini siyasi, sosyal ve ahlaki cepheden incelemiştir. (Bayrakdar, 2012: 22) Kendisi ayrıca İbn-i Haldun'dan etkilenerek onun ekolünü devam ettiren bilim adamları arasında yer almıştır. (Bayrakdar, 2012: 104)

\section{5. İslam Medeniyetinde Bilime/ Sosyal Bilimlere Bakış Geleneği}

İslam medeniyeti, bilimsel gelişmelere öncülük ettiği yüzyıllar içerisinde kendi değer yargıları ve dünya görüşü doğrultusunda bir bilim anlayışı da geliştirmiştir. Bu anlayışın, belli prensipleriyle modern dönem bilimine 1şık tutarak zamanla evrensel bilim anlayışı haline geldiğini söyleyebiliriz. Buna karşılık aynı anlayış bazı yönleriyle Batılı dünya görüşüne ve dolayısıyla bilim anlayışına nüfuz etme imkânı bulamamıştır. Belki de günümüz dünyasında karşılaşılan ciddi bazı problemlerde İslam medeniyet mirası ve bilim anlayışının bu bir takım zenginliklerinden uzak kalışımızın da önemli etkisi vardır.

Ünlü bilim tarihçisi Prof. Dr. Fuat Sezgin, İslam medeniyetinin -800 yıl sürerek 16. Yüzyıl sonlarına kadar ulaşan bilimsel yaratıcılık döneminde- kendine has birtakım prensipler geliştirdiğini savunmaktadır:

"Ben şahsen ylllar boyunca İslam bilimler safhasinın kendine has prensipleri olarak şunlara ulaşabildiğini saniyorum: 1. Adil tenkit prensibi 2. Vazıh bir tekâmül kanunu düşüncesi 3. Kaynak zikretmede diğer kültür dünyalarında olduğundan daha çok gösterilen gayret 4. Bilim tarihi yazarlı̆̆ının 10. yüzyıldan itibaren ortaya çıkışı ve gelişmesi 5. Tecrübe ile teori arasında bir denge kurma prensibi ve tecrübenin araştırmada sistematik olarak kullanılacak bir vasıta olarak yer alması 6. Uzun süreli gözetleme prensibi; bunun sonucu olarak rasathanelerin icadl 7. Bilimin sadece kitaptan değil, hocadan ve kitaptan ögrenilmesi; buna bağlı olarak ilk üniversitelerin ortaya çıkışı." (Sezgin, 2010: 10)

Görüldüğü gibi burada; eleştirel ama adil bir bakış açısı, ilerleme ve mükemmele ulaşma hedefi, bilim adamının emeğine saygılı ve emek hırsızlığına karşı tutum, bilimsel birikim sürecini takip, teoriyi ve pratiği birlikte yükseltme çabası, sabır - sebat ve istikrar, düzenli ve sistematik 
eğitim prensipleri öne çıkmaktadır. Günümüz bilim anlayışı açısından bakıldığında bunlar bu alanın zaten olmazsa olmazları olarak görülebilir. Ancak 8-16. Yüzyıl arası dönem söz konusu olduğunda bu temel prensiplerin bilim tarihinde çı̆̆ır açan ve günümüz bilim anlayışına ışık tutan düşünceler olduğu gerçeğiyle yüzleşmek durumunda kalırız.

İslam medeniyetinin, ilk dönemlerinden başlayarak sekiz asır kadar devam ettirdiği bu bilimsel anlayış ve yüksek performansın kaynağını, bu medeniyetin temel dini referansında yani Kur-an'da ve Hazreti Peygamberin sünnetinde aramak gerekir. Zira her medeniyetin oluşturduğu bir bilgi birikimi vardır ve bu bilgi birikimi o medeniyetin temel referanslarından beslenerek şekillenir.

Kur-an'1 Kerim'in ilk emrinin "yaratan rabbinin adıyla oku” (Alak 96/1) şeklinde olması ve Hazreti Peygamberin meşhur bir hadisi şerifinde "Çin'de de olsa ilmi arayınız. Çünkü ilim ögrenmek her Müslüman'a farzdır..." (Câmiu's Sağîr, 1/310, H. No: 640) buyurması, İslam'ın ilme verdiği önem konusunda fikir vericidir. Ayrıca; "Hiç bilenlerle bilmeyenler bir olur mu?" (Zümer 39/9) ayet-i kerimesini ve "Hikmet, (değerli bilgiler) müminin yitik malıdır, onu nerede bulursa almaya daha hak sahibidir" (Tirmizi, "İlim" 19; İbn Mâce, "Zühd" 17), "faydasız ilimden Allah'a sığınırım" (Tirmizi, "Daavat", 68) hadisi şerifleri de konuya 1şık tutmaktadır.

Söz konusu ayet ve hadisler derinlemesine incelendiğinde, burada salt ilmin önemine vurgu yapılmakla kalınmadığı, aynı zamanda ilim tahsili ile ilmi çalışmanın amaç ve kaynağı ile ilgili sinırlar da çizildiği görülmektedir. Örneğin; Çin'de de olsa ilmin aranması emri ile birinci olarak ilmin evrenselliğine vurgu yapılmakta, ikinci olarak ise onun elde edilebilmesi için en ağır meşakkatlere bile katlanmaktan kaçınılmaması gerektiği ifade edilmektedir. Bu söz; bir bilgi ya da buluşun "gâvur icadı" denilerek dışlanması anlayışıyla taban tabana zıttır.

Demek ki; bir bilgi Gayr-1 Müslimlerin elinde ve en uzak diyarlarda da bulunsa onlardan öğrenilmelidir. Bu konuda bir sınırlandırma yoktur. Sınırlandırma, ilmin kaynağıyla değil, niteliğiyle ilgili konulmaktadır. Bu noktada faydasız ilimden Allah'a sığınma sözüyle, elde edilecek ilmin faydalı olması gerektiği üzerinde durulmuş, faydalı olmayan, yani zararlı ve hatta lüzumsuz bilgiden kaçınılması gerektiği vurgulanmıştır. Okunacak olanın, yaratan rabbin adıyla okunması emri de hem vahyedilenler hem de yaratılanlar üzerinde bilgi edinilirken yaratıcının asla unutulmaması, dolayısıyla bilginin iyilik, doğruluk, güzellik, adalet ve fayda için tahsil edilmesi gerektiğine işaret etmektedir.

$\mathrm{Bu}$ noktada faydanın ölçüsünün ne olduğu, kime göre, ne için ve nasıl bir faydadan bahsedildiği şeklinde yeni sorular gündeme gelebilir? Bahsi geçen hadisi şerifte genel bir ifade kullanılmış ve detaya inilmemiş olmakla birlikte İslam dininin sevgiyi, barışı ve merhameti temel alan umumi kaideleri burada kastedilen fayda hakkında bize genel bir fikir verebilir. Ayrica ortalama bir akıl, mantık, vicdan ve adaletle bakan insanların fayda kavramı üzerinde az çok uzlaşabileceklerini düşünebiliriz. Örneğin insanın akıl ve ruh sağlığı, toplumsal refah ve huzur, insana ev sahipliği yapan tabiatın korunması gibi esaslar, ortalama bir insanı herhalde fayda kavramı etrafında birleştirebilecek esaslar olmalıdır. Bireysel, bir topluma has ya da kısa vadeli menfaatler uğruna diğer bireylerin, toplumların ya da tabiatın tahrip edilmesi ise makul bir bakış açısıyla herhalde fayda kapsamı içinde değerlendirilemez.

İslam medeniyetinde yetişen ilim adamlarının Hint'ten, Çin'den, Yunan'dan gelen bilgileri büyük bir iştiyakla öğrenip yine büyük bir hızla geliştirmelerinin altında yatan motivasyonun, yukarıda vurgulanan ilahi kaideler olduğu anlaşılmaktadır. İşte bunun için İslam bilim adamları; gerek insanın kendisine gerekse onu çevreleyen tabiata dair bilgileri araştırıp öğrenirlerken, bu faaliyete yaratıcı tarafından tanzim edilmiş bilgilerin iyilik ve güzellik için keşfedilmesi gözüyle bakmışlardır. Bunun için İslam medeniyet dairesi içinde dini bilgi ve bilimsel bilgi arasında hiçbir zıtlık görülmemiş, böyle bir zıtlık olabileceği düşünülmemiştir. Aksine dini bilgi her zaman bilimsel bilgi için itici bir güç olarak algılanmış ve pratikte de öyle de olmuştur. 
Yine İslam medeniyetinin bilime öncülük ettiği dönemlerde ortaya konan teknik icatların; tabiatın dengesini bozmayan, ona zarar vermeyen, sadece onunla uyum içinde fayda sağlamayı hedefleyen icatlar olmaları da, her yönüyle bir bütün teşkil eden ilahi düzene saygının gereğidir. İnsan dahi, bu uyumlu düzenin bir parçasıdır ve düzenle savaşmaya hakkı yoktur. Üstelik insanın pragmatist (faydacı) amaçlarla girişeceği böyle bir savaş insana aslında fayda sağlamayacak, aksine zarar ve yıkım getirecektir.

$\mathrm{Bu}$ anlayışın, insanı doğayla mücadele eden ve onu kontrol altına alması gereken bir canlı olarak tanımlayan modern Batı anlayışıyla taban tabana zıt olduğunu söyleyebiliriz. Batılıların Aydınlanma felsefesi ve modern dönem yaşam tarzının Francis Bacon'ın bu konudaki düşüncelerinden önemli ölçüde etkilediğini söyleyebiliriz. "Onun felsefesi bilgiyi, insanlığ doğaya egemen kllacak bir güç olarak betimler. (...) Ona göre doğaya egemen olmak gerekir; bu nedenle önce doğayı tanımak gerekir. " (Keha, 2016: 118, 130). Bu görüş; malını, mülkünü, eşini, çocuklarını, hatta kendi gençliğini, vaktini, bedenini ve dolayısıyla da içindekilerle birlikte bütün dünyayı insana verilmiş, korunması kollanması gereken bir emanet olarak gören İslam medeniyet algısından son derece uzaktır. İslam medeniyet mirası içinde insan; tabiatı çatışmak, yenmek ve kontrol altına almak için değil, onunla uyum içinde yaşamak için keşfeder.

Tabiatı ve insanı aynı yaratılmışlar bütününün bir parçası olarak algılayan ve dolayısıyla parçayı çözümlemeye çalışırken onu bütünden koparmayan anlayış, İslam medeniyet havzasında yetişen bilim adamlarının çok yönlü çalışmalar yapan insanlar olmalarını beraberinde getirmiştir. Bu noktada bilimsel bilgi ile diğer bilgi türleri birlikte ele alınıp incelenmiş, fizik ve metafizik, beden ve ruh birlikte çözümlenmiştir. Aynı şekilde İslam medeniyetinin yetiştirdiği bilim adamları çalışmalarını belirli bir alanla sınırlı tutmamış ve fizik, kimya, astronomi, tıp, psikoloji ve sosyoloji gibi birçok alanı aynı anda kucaklayan multidisipliner bir çaba içine girmişlerdir.

Branşlaşma ve bir branşın içine sıkışıp kalma hali günümüz dünyasında bilimsel bilgi birikiminin olağanüstü boyutlarda artmış olmasının doğal bir sonucu olarak da değerlendirilebilir. Ancak bu gerekçe aslında bir bütün olan yaratılmışlar âlemini parçalara ayırıp bu parçaları birbirinden kopuk değerlendirmenin getireceği yakın körlüğünü mazur gösteremez. Bu körlüğün yol açacağı eksikliklerin kabul edilebileceği anlamına da gelemez. Dolayısıyla insanlık günümüzün son derece zengin bilgi birikimi içinde de çok yönlü, multidisipliner bilim anlayışını canlandırmanın yollarını üretmek zorundadır.

Bilimsel anlayışın İslam bilim adamları eliyle tam anlamıyla sistematik bir çizgiye oturtulduğunu söyleyebiliriz. Bilim tarihinin gördüğü en büyük beyinlerden olan El Biruni; önceki medeniyetlerin bilim anlayışını şöyle eleştirmektedir:

\begin{abstract}
“Hindistan'da, Yunan ve Roma topraklarında her şeyin bir putu ve ilahı vardır. Hatta hırsızlık ilahları bile. Durum bu olunca bu kültürlerin bilginleri, adeta her şeyi tabu gibi görme psikolojisine sahip olduklart için nesnelere sadece dişarıdan bakarak ve zihni çıkarımlarla düşünce üretmişlerdir. Nesnelerin içine dokunmayı gerektiren, deney ve tecrübeye dayanan bilim üretememişlerdir." (Bayrakdar, 2012: 9)
\end{abstract}

Görüldüğü gibi İslam medeniyeti, Auguste Comte'un 19. yüzyılda aşılmaya başlandığını düşündüğü teolojik ve metafizik aşamaları daha ilk asrından $(6-7$. yüzyıldan) itibaren aşıp somut, deneysel ve nesnel bilim anlayışına ulaşmıştır. Yukarıdaki saptamayı yapan El Biruni ise kendi ulaştıkları bu anlayışa Comte'tan 8 asır önce, 11. yüzyılda dikkat çekmiştir. Bilim konusunda böyle bir anlayışın hâkim olduğu İslam medeniyeti her alanda altın çağını yaşarken, Orta çă̆ Batı Medeniyetinin bir çeşit Hıristiyanlık yorumundan hareketle bilime sırtını dönerek her alanda karanlığa gömülmüş olduğu bilinmektedir. Orta çağ Avrupa'sında bilimsel çalışmaların dini gerekçelerle engellenmesi ve ancak Katolik kilisesinin prangalarından kurtulduktan sonra önünün açılabilmesi; İslam medeniyetinin aksine Batı'da din-bilim karşıtlı̆̆ anlayışının yerleşmesine yol açmıştır. Bunun için aydınlanma dönemi filozofları ve modern 
dönem bilim adamları hep dinsel dönemin aşılarak geride bırakılıp bilimsel döneme geçildiği/ geçilmekte olduğu kabulü üzerinden tez üretmişlerdir.

Böylece İslam medeniyetinin “Orta Çağ” olarak anılan dönemde bilimsel bilgiye yaptığı katkılar Batı medeniyeti tarafından transfer edilmiş ve bu kez onlar tarafından kendi yorumlarıyla geliştirilerek insanlığa sunulmuştur. Batı medeniyeti; kendi geliştirdiği -bilime ket vuran, çarpıkdin yorumunun prangalarından kurtularak bilimsel gelişme evresine girmeyi başarmış, ancak bu kez de bilime bakış, onu yorumlayış konusundaki çarpıklıklarıyla yüzleşmek durumunda kalmıştır.

"Ortaçă̆g'da evreni yaratan ve onu sürekli yöneten tanrı aracılığılla açıklanan evren, modern dönemde, doğa yasaları tarafindan yönetilip, fizik ve matematik terimleriyle anlaşılabilen maddi bir varlık alanına dönüşmüş̧ür." (Keha, 2016:

118)

Batı medeniyetinin egemenliğinde/ öncülüğünde geliştirilen bilim ve teknik anlayışının doğurduğu problemler sadece Batı medeniyetiyle sınırlı kalmamış, birey ve toplum düzeyinde insanlığ ve hatta onu çevreleyen tabiatı küresel boyutta birçok açıdan olumsuz yönde etkilemiştir. Kirlenen denizler, tahrip olan atmosfer tabakaları, nitelik değişimine uğrayan mevsimler, hızla nesli tükenen bitki ve hayvan türleri, her gün bir yenisi türeyen hastalıklar söz konusu olumsuzluklara doğa bilimleri açısından verilebilecek örneklerden bazılarıdır.

Aynı boyutta olumsuzlukları sosyal bilimler alanında da görebilmek mümkündür. Batılı tarihçi ve sosyologlar, kendi tarihsel ve toplumsal tecrübelerinin evrenselliği iddiasından hareketle diğer toplumların da kendileriyle aynı tecrübeleri yaşayacakları iddiasında bulunmuşlardır. $\mathrm{Bu}$ anlayış, evrimleşme sürecinde Batılıların öncü, diğer toplumların ise takipçi durumunda oldukları, dolayısıyla bu az gelişmiş toplumların Batılılar tarafindan yönlendirilmeye, güdülmeye ve sömürülmeye müstahak oldukları anlayışını yerleştirmiştir. Batılıların iktisadi anlayışı ve bunun üzerine inşa edilen iktisat bilimi de dünyada açık bir sömürüye ve maddi refah dengesizliğine yol açmıştır. Batılılar, antropoloji ve sosyal antropolojiyi de sömürülecek geri toplumları çözümleme amacı için bir araç olarak kullanmışlardır.

Bugün doğa bilimlerinde ulaştıkları seviyeden iktisadi, siyasi ve askeri üstünlük devşiren Bat1 Medeniyeti, ne sömürdüğü toplumlara ne de kendi toplumlarına refah ve huzur sağlayabilmektedir. Sömüren ve sömürülen ülkeler arasındaki gelir düzeyi uçurumu bir yana Batılı ülkeler kendi toplumları içerisindeki toplumsal sınıflar arasında da böyle bir uçuruma sahne olmaktadırlar. Örneğin bugün Batı medeniyetinin başat gücü ABD, -2018 başı itibarıyla- bir yanda 46'sı on milyar doların üzerinde şahsi servete sahip olmak üzere 563 milyardere (www.forbes.com) diğer yanda geceleri metro istasyonu vb. yerleri mesken tutan 553.742 evsize (homeless) sahiptir (https://endhomelessness.org).

Sosyal problemler gelir dağımı adaletsizliğiyle sınırlı kalmamakta; maddi tatminsizlik, manevi boşluk, ırk ayrımcılığı, dini ya da siyasi fanatizm gibi etmenler yaygın psikolojik problemlere, adi suçlara, intihar vakalarına, cinsel sapkınlıklara, dağılan ailelere, yaşlanan nüfus problemine, her çeşit suçu işleyen mafya ve terör yapılanmalarına zemin hazırlamaktadır. 2017 yılına ait verilere göre sadece bir yıl içinde 1.247.321 şiddet olayının yaşandığ 1 ve 17.284 kişinin cinayete kurban gittiği ABD'de 135.755 tecavüz ve 319.356 de soygun vakası gerçekleşmiştir. (https://ucr.fbi.gov/ ...table-1) Cinayetlerden \% 12,3'ünün bizzat aile üyelerince işlenmiş olmas1 ise (https://ucr.fbi.gov/ ...homicide) bir toplumu ayakta tutması beklenen değerler sistemindeki çöküşün en bariz göstergesidir. Aynı türden bir başka gösterge ise bu ülkede ortalama her yıl 44.965, günde ise 123 kişinin intihar ederek öldüğüne dair Amerikan İntihar Önleme Derneği'nin (AFSP) bize sunduğu verilerdir (https://afsp.org/).

İslam'ın ırk vb. ayrımcılıkları reddeden öğretisi; din ayrımı dahi yapmaksızın herkese adil davranmayı emreden hukuk anlayışı; faiz, israf, karaborsacılık gibi haksız kazanç ve harcamaları men eden ekonomi anlayışı; bireye yüklediği kul hakkı, akraba hakk1, komşu hakk1 gibi 
sorumluluklar; zekât, sadaka, infak gibi sosyal adalete katkı sağlayan ibadetleri psikoloji, sosyoloji, sosyal antropoloji, ekonomi, siyaset bilimi, hukuk gibi modern disiplinlerin penceresinden ele alınıp irdelenmelidir.

Örneğin bugün sosyoloji biliminin kullandığı toplumsal dayanışma, toplumsal tabakalaşma, toplumsal hareketlilik vb. terimler İslam dininin terminolojisiyle yorumlanıp bilim anlayışıla yoğrulduğu zaman sosyal sorunların çözümünde çok daha etkin rol üstlenecek toplum bilimlerine ulaşılması beklenebilir.

\section{Sonuç ve Öneriler}

Birçoğunun kuruluşuna, birçoğunun da gelişimine vaktiyle Müslümanların öncülük ettiği bilim dallarının bayrağını bugün Batılıların taşıdığı yadsınamaz bir gerçekliktir. Batılılar yeniçağdan bugüne gerçekten bilimsel bilgi birikiminin artışına da, bilimin pratiğe uyarlanması anlamına gelen teknolojiye de şaşırtıcı ölçüde katkıda bulunmuş ve dünyanın çehresini değiştirmişlerdir.

Bu değişim, insan yaşamı için olumlu sayılabilecek katkılarının yanı sıra -yukarıda da belirtildiği gibi- insan ve doğa üzerinde tahribata da yol açmıştır. Elbette ki söz konusu tahribatın etkisi altında kalınarak bu bilimsel ve teknik birikimin bütünüyle reddedilmesi düşünülemez. Aynı şekilde olumlu katkıların etkisinde kalınarak mevcut bilimsel ve teknik gelişmelere bütünüyle ve sorgulanmadan onay verilmesi de kabul edilemez. Neticede bilimsel ve teknik bilgiler, yorumlanış ve uygulanış biçimleriyle anlam kazanmaktadırlar.

Dolayısıyla Batı medeniyeti içerisinde zenginleştirilen mevcut bilgi birikiminin de insanı ve doğayı tüm yönleriyle bir bütün olarak ele alıp bütünsel faydayı gözeten bir anlayışla baştan yoğrulması gerekmektedir. Böylelikle insanlığın ortak mirası olan bilim; bir kısım insanların kısa vadeli ve tartışılabilir menfaatleri uğruna diğer insanları, toplumları ve tüm doğayı tahrip etme üzerine kurulu anlayıştan kurtarılmış, adil bir bakış açısıyla tekrar yorumlanarak geliştirilmiş olacaktır.

Tarihte Mezopotamya, Mısır, (Yunan/Roma eliyle) Batı, Hint, Çin, İslam ve bir kez daha Batı medeniyetleri nasıl ki kendilerinden önceki birikimleri alıp özgün bakış açılarıyla geliştirmiş ve bilime dönemsel olarak bayraktarlık yapmışlarsa İslam medeniyetinin de tekrar aynı rolü üstlenmemesi için hiçbir sebep olamaz. Ancak bunun gerçekleştirilebilmesi için uzun vadeli ve uzun soluklu bir çalışmaya ihtiyaç vardır.

Doğayla mücadele halinde olan değil, aksine onun bir parçası olup onunla uyum içinde yaşayan insan tahayyülü; tüm bilimleri aynı gerçeği çeşitli boyutlarıyla keşfetmenin araçları, yani bir bütünün parçaları olarak algılayan bütüncül bilim anlayış1; iktisadi, siyasi, hukuki ve sosyal alanlarda ayrımcılıkları reddederek herkesi kucaklayıcı adalet bilinci ve toplumsal dengeleri yerli yerine oturtacak dayanışma mekanizmaları İslam medeniyetinin günümüz toplum bilimlerine sunabileceği paha biçilmez hazineler durumundadır.

Söz konusu medeniyetin mensupları, öncelikle bu konudaki ihtiyaç ve gerekliliği idrak etmeli, o ihtiyacı giderecek potansiyele malik olduklarını fark ederek özgüven kazanmalıdır. İslam dünyasının içinde bulunduğu olumsuzlukların sebepleri üzerinde kafa yormalı, içeriden kaynaklanan problemler noktasında özeleştiri mekanizmaları geliştirmeli, hatalardan ders alarak bunları düzeltme yoluna gitmelidir. Geçmişle övünme davranışı; sloganik tarzdan ve günümüzün olumsuzluklarına karşı avunarak teselli bulma işlevinden kurtarılarak geleceğe yönelik bir atılımın zemini haline getirilmelidir. İhtiyacın getirdiği motivasyon, farkına varılmış potansiyelin getirdiği özgüven ve yapıcı özeleştiri kültürü birleşerek sabırlı ve yoğun bir çalışma temposuna dönüştüğünde ise İslam medeniyetinin bilim tarihinde yeni bir dönem için tekrar söz sahibi olmasını engelleyebilecek hiçbir sebep kalmayacaktır 


\section{Kaynakça}

Akün, Ö.F. (2002). Kaşgarlı Mahmud, İslam Ansiklopedisi, (ss. 9-15). Cilt 25, Ankara: Türkiye Diyanet Vakfı Yayın Matbaacılık ve Tic. İşletmesi.

Avcı, C. (2004). Mes'ûdî, Ali b. Hüseyin, İslam Ansiklopedisi, (ss. 353-355). Cilt 29, Ankara: Türkiye Diyanet Vakfı Yayın Matbaacılık ve Tic. İşletmesi.

Bayrakdar, M. (2012). Íslam Bilim Adamlarl, İstanbul: İnkılab Yayınları.

Çelebi, İ. (2010). Sünnetullah, İslam Ansiklopedisi, (ss. 159-160). Cilt 38, Ankara: Türkiye Diyanet Vakfı Yayın Matbaacılık ve Tic. İşletmesi.

Giddens, A. (1997). Pozitivizm ve Eleştiriciler, (Ed: T. Bottomore, R. Nisbet), Sosyolojik Çözümlemenin Tarihi, (Çev: Levent Köker), (Yayına Hazırlayan: Mete Tunçay, Aydın Uğur), 2. Bask1, Ankara: Ayraç Yayınları, s. 246-247 (243-290).

Giddens, A. (2000). Sosyoloji, Ankara: 2000, Ayraç.

https://afsp.org/about-suicide/suicide-statistics/

https://endhomelessness.org/homelessness-in-america/homelessness-statistics/state-ofhomelessness-report/ (Erişim Tarihi: 05 Kasım 2018).

http://www.felsefe.gen.tr/felsefeye_giris/bilgi_turleri_nelerdir_bilginin_turleri.asp, (Erişim Tarihi: 10 Eylül 2015).

http://felsefe.konulari.org/bilimsel-bilgi-nedir.html, (Erişim Tarihi:10 Eylül 2015).

https://www.forbes.com/billionaires/list/\#version:static_country:United\%20States

Tarihi: 05 Kasim 2018).

https://ucr.fbi.gov/crime-in-the-u.s/2017/crime-in-the-u.s.-2017/tables/table-1

https://ucr.fbi.gov/crime-in-the-u.s/2017/crime-in-the-u.s.-2017/topic-pages/expanded-homicide

Kaçalin, M. (2002). Kutadgu Bilig, İslam Ansiklopedisi, (ss. 478-480). Cilt 26, Ankara: Türkiye Diyanet Vakfı Yayın Matbaacılık ve Tic. İşletmesi

Keha, M. K. (2016). Modern Felsefenin Öncüleri: Descartes ve Bacon'da Yöntem Sorunu”, Atatürk Üniversitesi Edebiyat Fakültesi Sosyal Bilimler Dergisi, Say1: 56: 117-132.

Korkman, H. (2017). Ortaçağ İslam Felsefesinde Psikoloji ile İlgili Görüşler, Asya Öğretim Dergisi, 5(1) 12-27.

Sayılı, A. (1963). Orta çağ İslam Dünyasında İlmi Çalışma Temposundaki Ağırlaşmanın Bazı Temel Sebepleri (Avrupa ile Mukayese), Araştırma Dergisi, Cilt: 1, Sayı: 1: 5-71.

Sezer, B. (1985). Sosyolojinin Ana Başllklarl, İstanbul: İstanbul Üniversitesi Yayınları.

Sezgin, F. (2011). Bilim Tarihi Sohbetleri, Söyleşi: Sefer Turan, 3. Baskı, İstanbul: Timaş Yayınlar1.

Sezgin, F. (2008). İslam'da Bilim ve Teknik, C: 1, İstanbul: İ.B.B. Kültür A.Ş. Yayınları.

Sezgin, F. (2010). İstanbul İslam Bilim ve Teknoloji Tarihi Müzesi, İstanbul: İ.B.B. Kültür ve Sanat Ürünleri Tic. A.Ş.

Tezcan, N. (2009). Seyahatname, Íslam Ansiklopedisi, (s. 16-19). Cilt 37, Ankara: Türkiye Diyanet Vakfı Yayın Matbaacılık ve Tic. İşletmesi.

Ural, Ş. (1998). Bilim Tarihi, 2. Baskı, İstanbul: Kırkambar Yayınları. 
Yakıt, İ. (1984). Darwin'den Önce İslam Düsünürlerinde Evrimle İlgili Fikirler, İstanbul Üniversitesi Felsefe Arkivi Dergisi, İstanbul Üniversitesi Edebiyat Fakültesi Yayınevi, Sayı: 24: 101-122.

Zencirkıran, M. (2015). Sosyoloji, Bursa: Dora Basım-Yayın Dağıtım. 